\title{
Multi-scale modeling for prediction of distributed cellular properties in response to substrate spatial gradients in a continuously run microreactor
}

\author{
Lencastre Fernandes, Rita; Krühne, Ulrich; Nopens, Ingmar; Jensen, Anker Degn; Gernaey, Krist
}

Publication date:

2012

Document Version

Publisher's PDF, also known as Version of record

Link back to DTU Orbit

Citation (APA):

Lencastre Fernandes, R., Krühne, U., Nopens, I., Jensen, A. D., \& Gernaey, K. (2012). Multi-scale modeling for prediction of distributed cellular properties in response to substrate spatial gradients in a continuously run microreactor. Poster session presented at 11th International Symposium on Process Systems Engineering, Singapore.

\section{General rights}

Copyright and moral rights for the publications made accessible in the public portal are retained by the authors and/or other copyright owners and it is a condition of accessing publications that users recognise and abide by the legal requirements associated with these rights.

- Users may download and print one copy of any publication from the public portal for the purpose of private study or research.

- You may not further distribute the material or use it for any profit-making activity or commercial gain

- You may freely distribute the URL identifying the publication in the public portal 


\section{Multi-scale modelling for prediction of}

distributed cellular properties

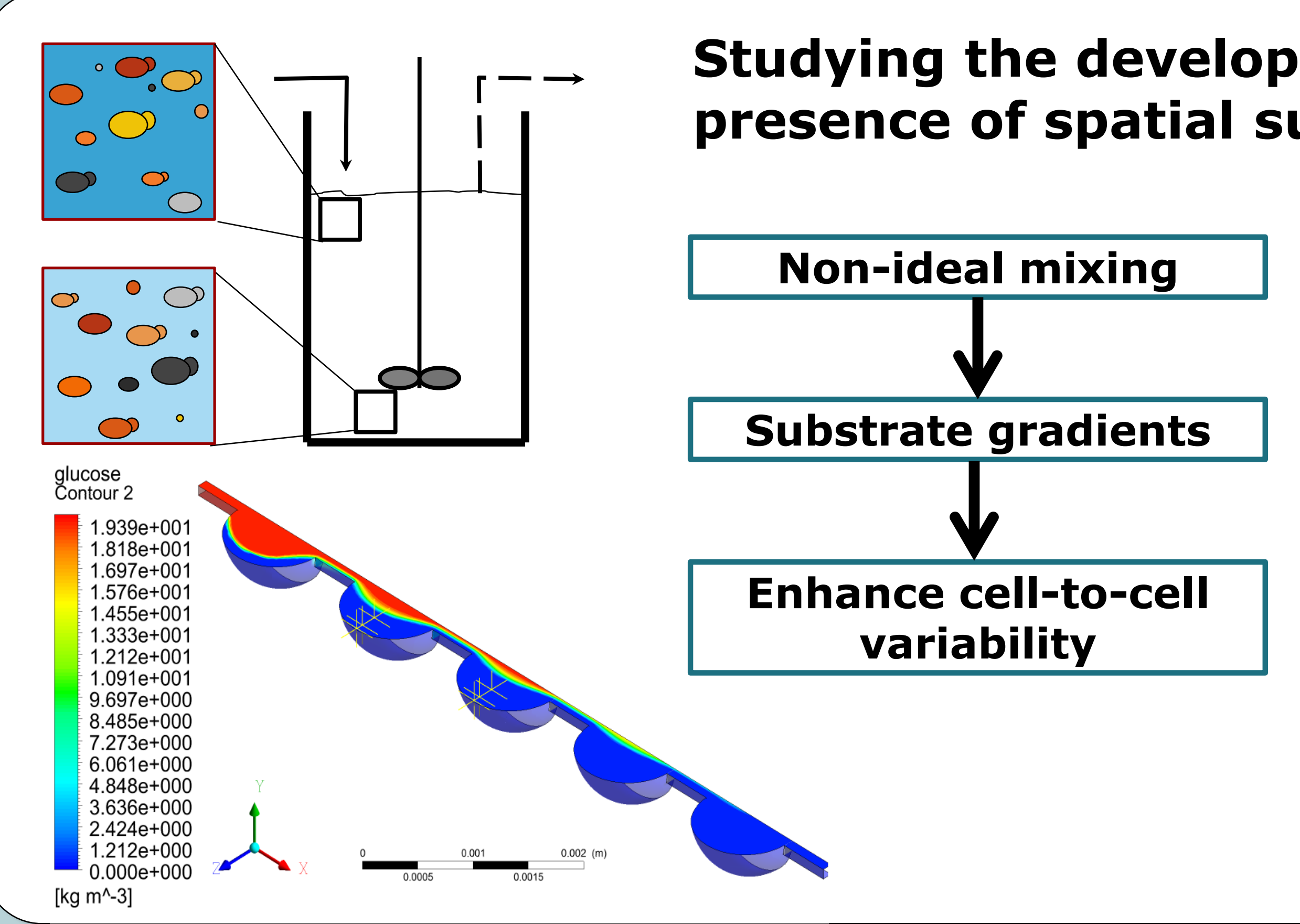

\section{Case study: Microbioreactor}

Inlet

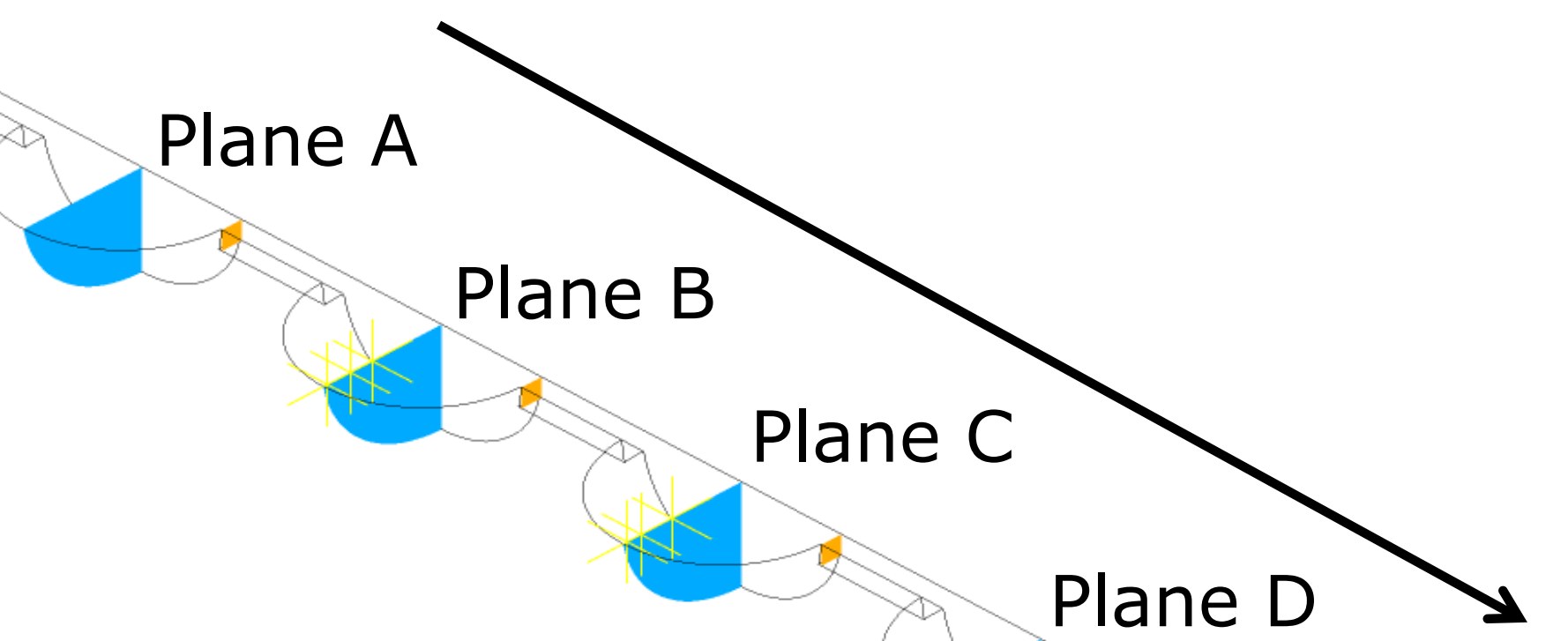

- Bubble flow-through reactor

$\rightarrow$ decrease biomass wash-out

- Total length of the reactor: $8 \mathrm{~mm}$

- Anaerobic growth of budding yeast

- Slow feed of glucose: $1 \mathrm{nl} / \mathrm{s}$ vs. $0.1 \mathrm{~nL} / \mathrm{s}$

- Laminar flow

- Incompressible fluids

- Diffusion is not taken into account

- Implemented in CFX 12.1 and the biological model was implemented using CEL language

- Hexaedral mesh with 32159 elements and 36535 nodes

- PBM discritized in $2 \times 20$ pivots using the fixed-pivot method

\section{Concentration profiles}

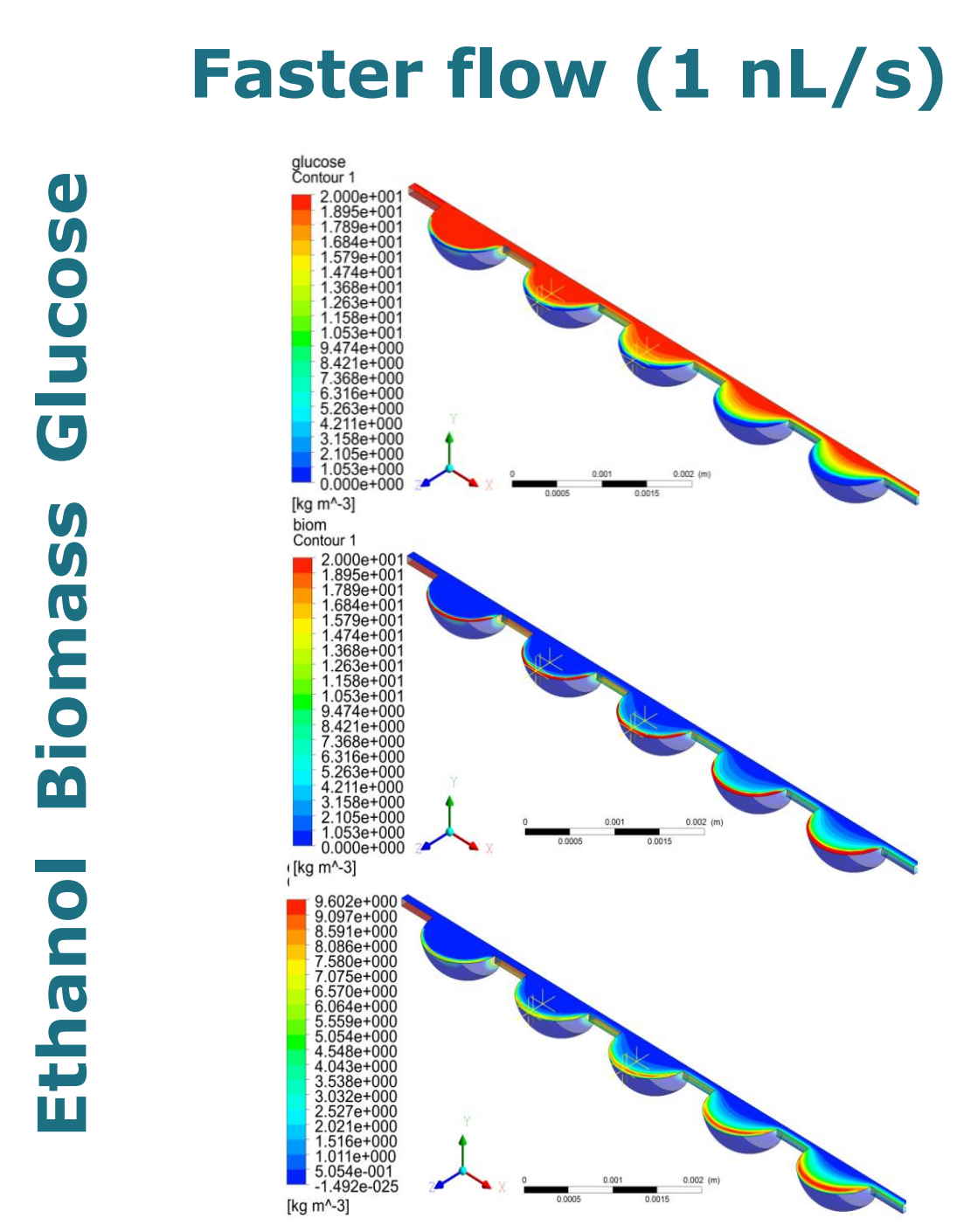

Slower flow $(0.1 \mathrm{~nL} / \mathrm{s})$

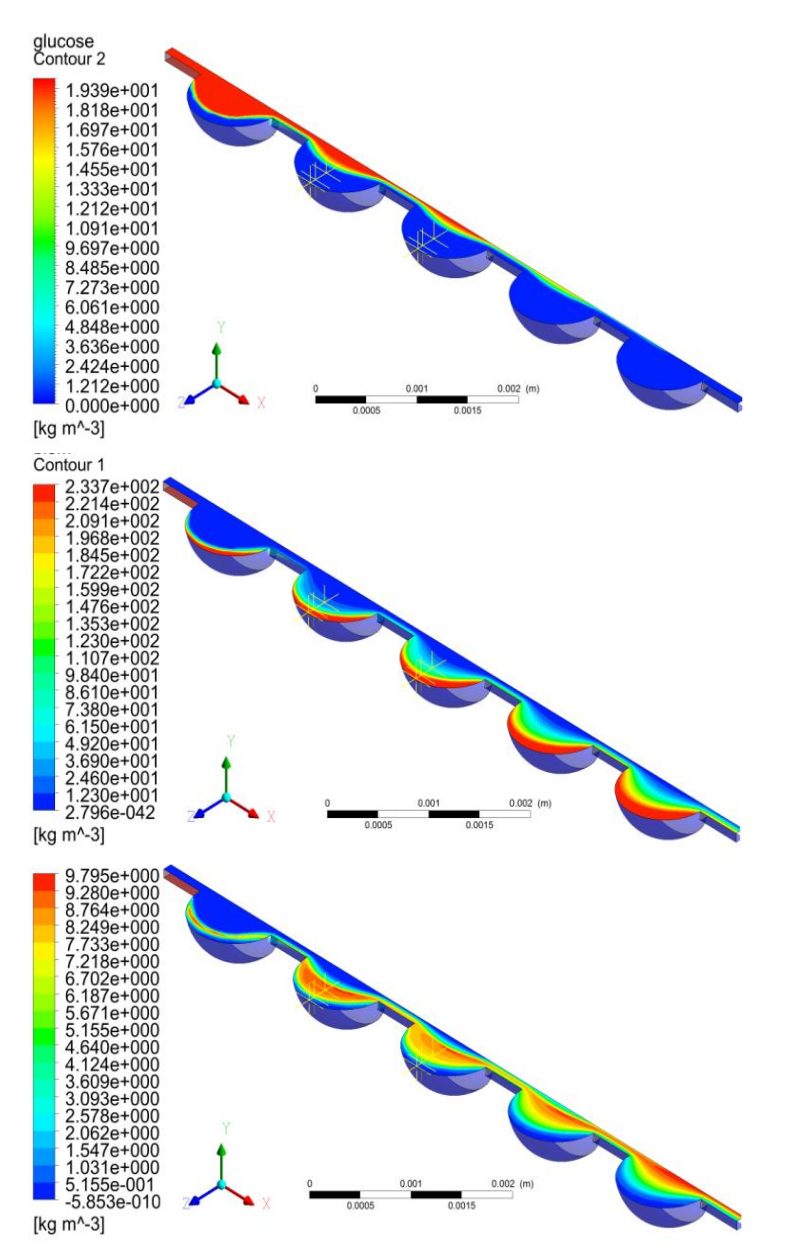

outlet 2-stage cell size structured PBM...

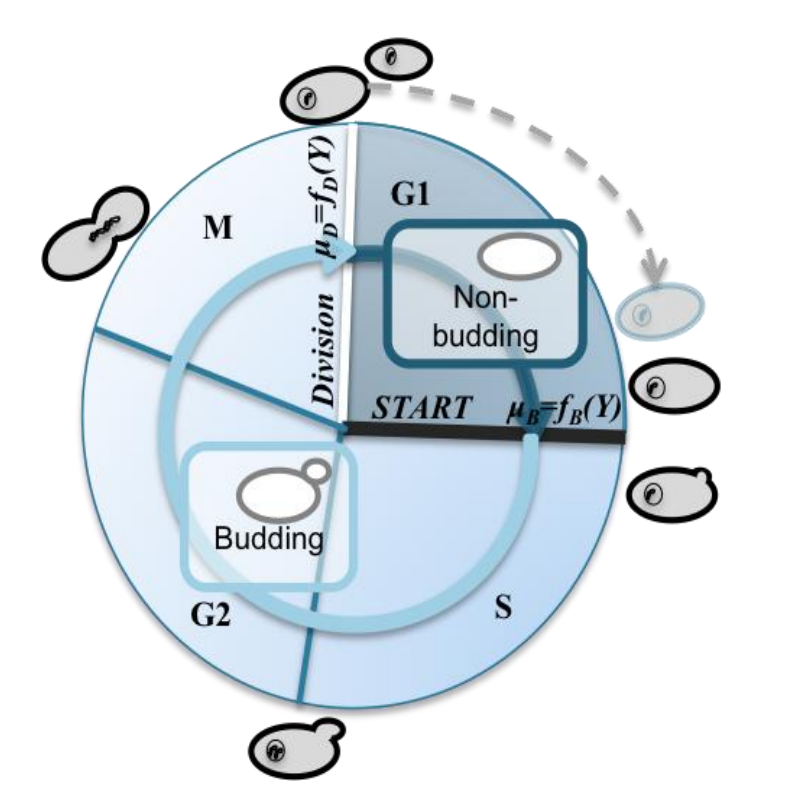

Critical Budding and Division Sizes as functions of the substrate concentration

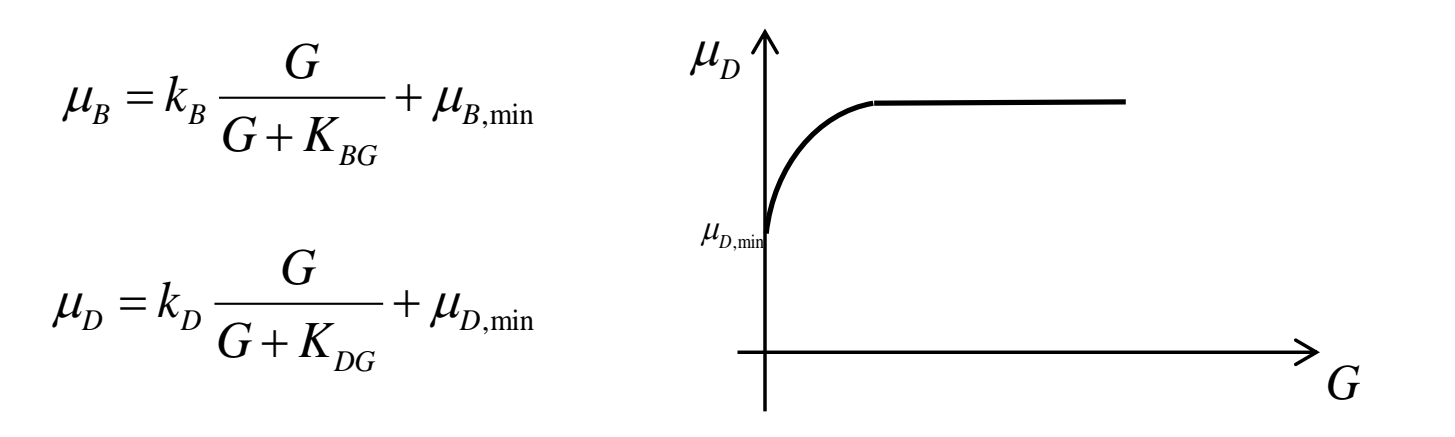

... coupled to an unstructured model

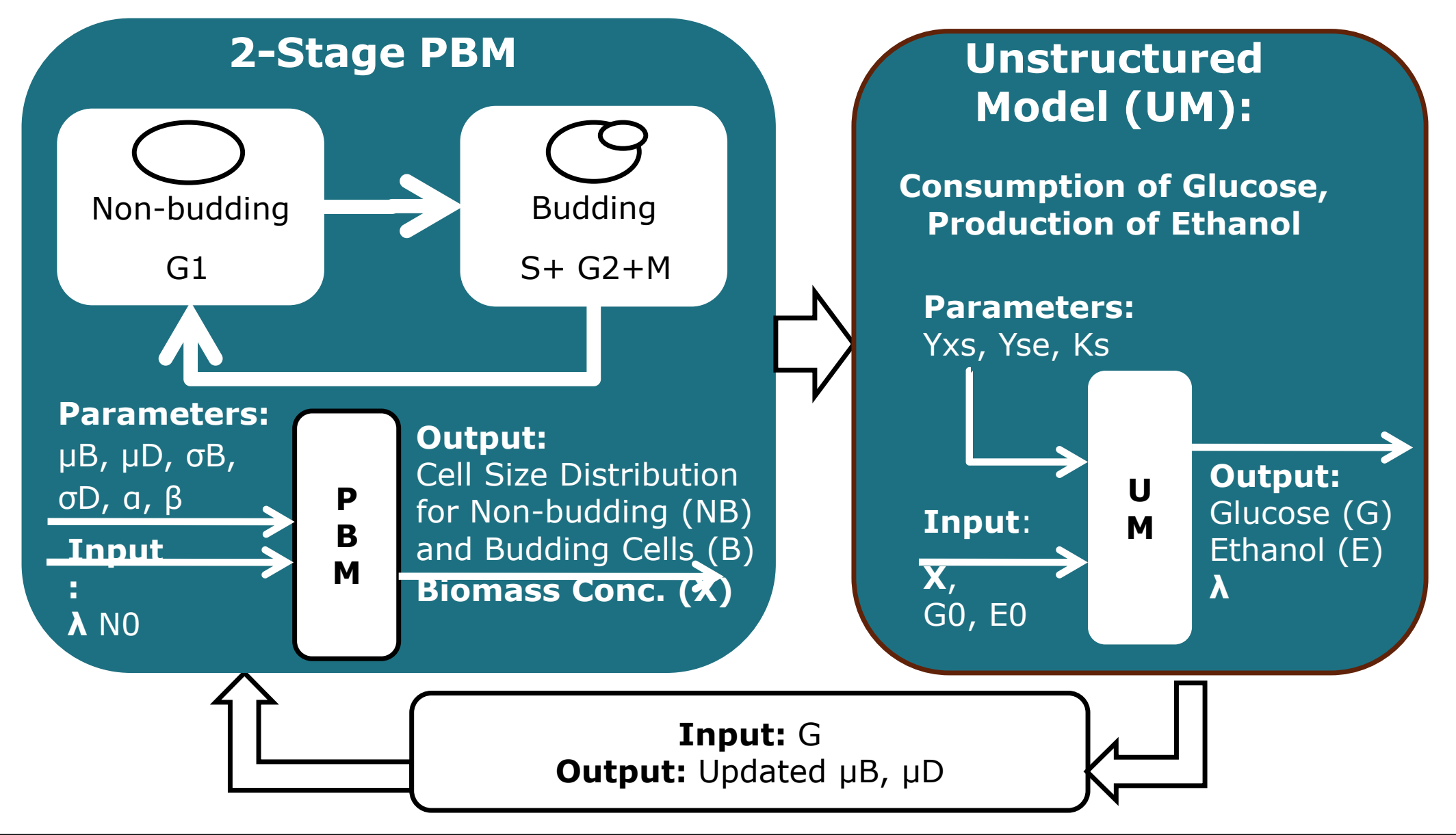

\section{Local Concentrations and distributions}

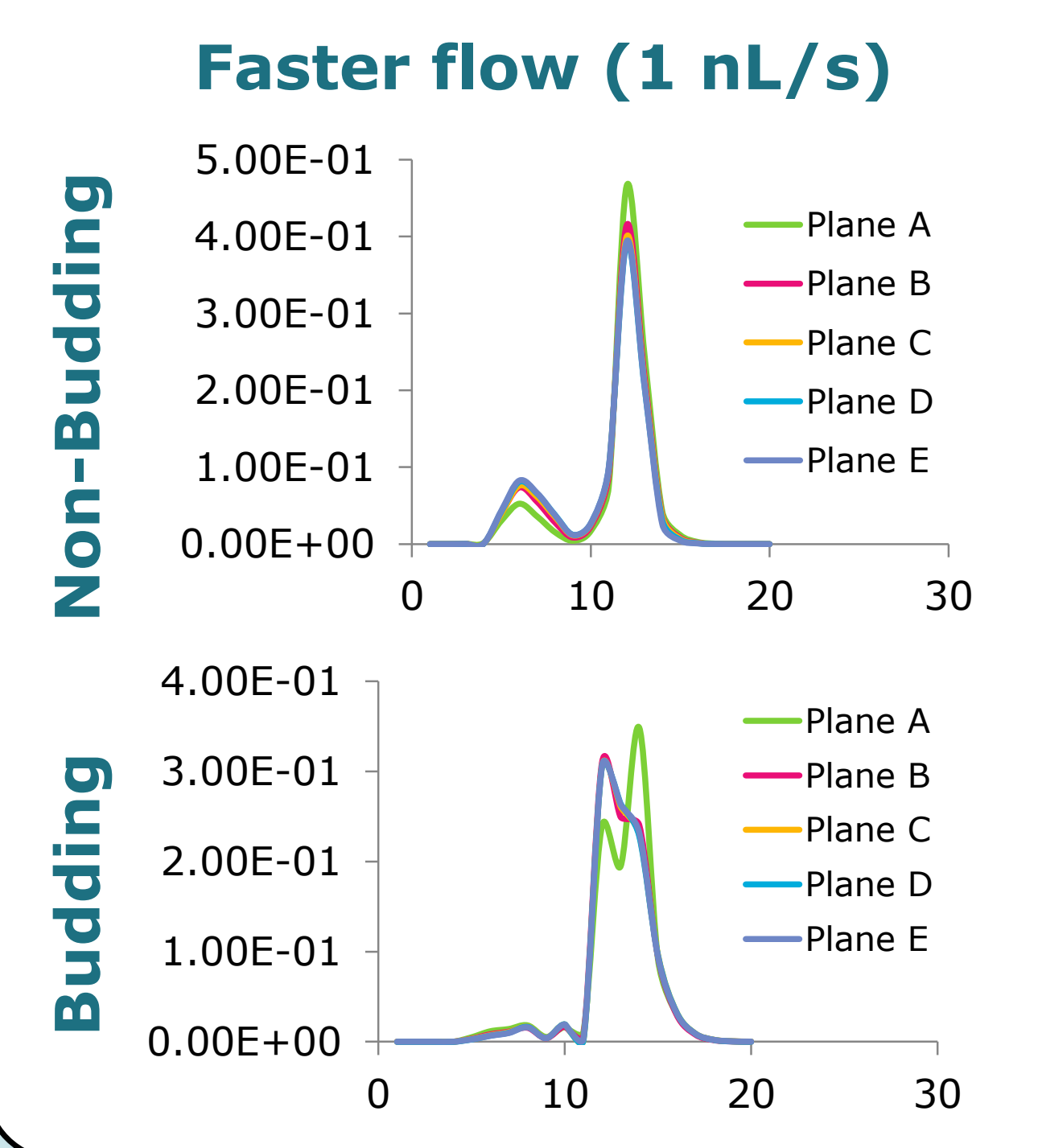

\section{Conclusion \& Outlook}

- Challenge in understanding the local distributions as they result from the interplay of flow and the population dynamics

- Proof-of-concept of integration of a CFD and PBM for multi-scale biological applications.

- In silico simulation of various scenarios: different flow conditions, cellular kinetics, etc.

- Experimental Validation: overall distribution of biomass, bulk concentrations and cell distributions at the outlet

\section{Rita Lencastre Fernandes}

Center for Process Engineering and Technology Dept. Chemical and Biochemical Engineering Technical University of Denmark rIf@kt.dtu.dk

\section{Acknowledgments}

Danish Council for Strategic Research (Project no. 09065160) and ERA-Net Industrial Biotechnology (Project no. EIB.08.031) are acknowledged for the financial support. 